\title{
VITAMIN E AND SELENIUM DECREASED CORTISOL IN CATTLE
}

\author{
Mudroň, $P$. \\ Clinic of Ruminants \\ University of Veterinary Medicine and Pharmacy in Košice, Komenského 73, 04181 Košice \\ Slovakia
}

pavol.mudron@uvlf.sk

\section{ABSTRACT}

Twenty dairy cows with left abomasal displacement were used to investigate the effects of vitamin $\mathrm{E}$ and selenium treatment on blood cortisol in dairy cows stressed by omentopexy. The cows were randomly divided into two groups. Ten hours before surgery $6 \mathrm{~g}$ of DL- $\mathrm{a}$-tocopheryl acetate $\left(6 \mathrm{mg} \cdot \mathrm{kg}^{-1}\right)$ and $67 \mathrm{mg}$ of natrium selenite $\left(0.1 \mathrm{mg} \cdot \mathrm{kg}^{-1}\right)$ in a volume of $40 \mathrm{ml}$ were administered subcutaneously to 10 cows; the control animals $(n=10)$ received an equivalent volume of injectable water $(40 \mathrm{ml})$. The injection of vitamin $E$ and selenium produced a rapid rise $(\mathrm{P}<0.05)$ in blood $\alpha$-tocopherol and selenium concentrations. The serum vitamin $\mathrm{E}$ increased several times ten hours after vitamin $\mathrm{E}$ and $\mathrm{Se}$ injection and raised continuously to the highest average concentration of $21.6 \mathrm{mg} \cdot \mathrm{l}^{-1}$ at hour 24 after the surgery. The highest selenium concentration was seen ten hours after selenium administration with holding the increased concentrations in comparison to initial ones during the whole study. Serum cortisol increased in both groups after surgery. The highest cortisol concentrations were reached at one hour after surgery in the experimental and control group $\left(56.7 \pm 28.8\right.$ and $65.3 \pm 26.1 \mu \mathrm{g} . \mathrm{l}^{-1}$, respectively). A return to the levels similar to the initial ones was recognized 24 hours after the surgery. The ANOVA revealed a significant effect of vitamin $E$ and selenium injection on serum cortisol $(P<0.05)$. In conclusion, we have demonstrated that abdominal surgery resulted in typical stress changes with a weaker cortisol response to the abdominal surgery in animals treated with vitamin $\mathrm{E}$ and selenium.

Key words: cortisol; dairy cows; selenium; surgical stress, vitamin $\mathrm{E}$

\section{INTRODUCTION}

Peroxidative processes of lipids, proteins, carbohydrates as well as nucleic acids and their products can exert severe negative effects on cell membranes as well as biochemical pathways. Peroxidative processes and their products may regulate and influence the efficiency of an antioxidative 
system. An antioxidative system represented by enzymes and non-enzymatic antioxidants is responsible for maintaining the balance between production and neutralization of reactive oxygen species [12]. Lack of antioxidants can result in various pathological processes like myopathy, cardiomyopathy, embryonic degeneration, liver necrosis, and encephalomalacia [17]. Increased health problems around parturition are particularly problematic as they may greatly impact the productivity of dairy cows in the ensuing lactation [9]. Therefore, it is not surprising that considerable research efforts have focused on defining factors that may contribute to immune dysfunction during this critical period in the production cycle of dairy cows [26].

It has been demonstrated that a number of manipulations including transport [10], therapeutic manipulation [22], and surgery [2], increased secretion of cortisol from the adrenal cortex in cattle. Several studies demonstrated that the stress reaction has enhancing effects on free radical production, thus contributing to an increased lipid peroxidation in animals [21]. Although stress reactions are organised to protect the homeostatic state of animals, they contain elements that may either enhance or diminish susceptibility to the disease process; in many instances, however, stress reactions themselves may induce pathologic change [3].

The present trial was aimed to study the effects of vitamin E and selenium treatment on blood cortisol in dairy cows stressed by omentopexy.

\section{MATERIALS AND METHODS}

Twenty Holstein-Frisian lactating dairy cows, mean age $4.41 \pm 1.34$ years $(\mathrm{x} \pm \mathrm{SD})$, admitted for treatment of left abomasal displacement, were used in the study. All of them were within first six weeks after calving. Their mean body weight was $586 \pm 65 \mathrm{~kg}(\mathrm{x} \pm \mathrm{SD})$. They were randomly divided into two equal groups $(\mathrm{n}=10)$ according to the order of admission to the clinic. The surgery followed on the subsequent day to correct the abomasal displacement. Ten hours before surgery $6 \mathrm{~g}$ of DL-a-tocopheryl acetate (6 mg. $\left.\mathrm{kg}^{-1}\right)$ and $67 \mathrm{mg}$ of natrium selenite $\left(0.1 \mathrm{mg} \cdot \mathrm{kg}^{-1}\right)$ in a volume of $40 \mathrm{ml}$ were administered subcutaneously to 10 cows; the control animals $(n=10)$ received an equivalent volume of injectable water $(40 \mathrm{ml})$. Abdominal surgery (omentopexy) was performed in a standing position 16-
24 hours after admission. The mean duration of preparation for surgery lasted approximately 30-40 minutes, and the surgery approximately 40 minutes. Procaine-hydrochloride $(2 \%)$ was used for local anaesthesia. All experimental animals were housed in pens with straw bedding and were fed hay ad libitum. Concentrates were offered on the day after the surgery according to milk yield and had free access to water. No additional health disorders were diagnosed in the experimental animals and no supportive treatment was necessary. All cows recovered and left the clinic on day 4 or 5 after the omentopexy.

Blood samples were drawn from the jugular vein before vitamin $\mathrm{E} / \mathrm{Se}$ injection, just prior to surgery, immediately after surgery, then 15, 30, 60 minutes, and 2, 5, 10, and 24 hours after surgery. The blood samples were stored at $4{ }^{\circ} \mathrm{C}$ maximally for two hours before centrifugation. The serum samples were obtained and then stored frozen at $-80{ }^{\circ} \mathrm{C}$ until analysis. The a-tocopherol concentrations in the serum were determined in saponified samples by high performance liquid chromatography (HPLC) using a fluorescent detector. The concentrations of selenium in the serum were measured using the fluorimetric method of Rodriguez et al. [25]. The serum cortisol concentrations were determined by chemiluminescent enzyme immunoassay (Immulate Immulate $^{\varpi} 1000$ Cortisol immunoassay, DPC, L.A., USA).

Statistical analysis was carried out by a two-factorial analysis of variance (one repeated factor: time, one grouping factor: treatment) with the post hoc Bonferroni test (IBM SPSS Statistics 23, 2015). Significance was declared at $\mathrm{P}<0.05$.

\section{RESULTS}

The subcutaneous injection of vitamin $\mathrm{E}$ and selenium resulted in a rapid increase $(\mathrm{P}<0.05)$ in blood $\alpha$-tocopher$\mathrm{ol}$ and selenium concentrations (Table 1). The serum vitamin E increased to sixfold values ten hours after administration in the treated animals and rose continuously to the highest average concentration of $21.6 \mathrm{mg} . \mathrm{l}^{-1}, 24$ hours after the surgery. There were no changes in serum Vitamin E concentration in the control group during the study. The serum selenium concentrations of the experimental group showed a similar dynamic like $a$-tocopherol (Table 1 ). The highest selenium concentration was seen ten hours after 
Table 1. Concentrations of blood a-tocopherol, selenium, and cortisol in operated dairy cows after vitamin $\mathrm{E} / \mathrm{Se}$ or placebo treatment (mean \pm SD)

\begin{tabular}{|c|c|c|c|c|}
\hline Sampling time & Group & $\begin{array}{c}\text { a-tocopherol } \\
{\left[\mathrm{mg} . \mathrm{I}^{-1}\right]}\end{array}$ & $\begin{array}{l}\text { Selenium } \\
{\left[\mathrm{mmol} . \mathrm{I}^{-1}\right]}\end{array}$ & $\begin{array}{l}\text { Cortisol } \\
{\left[\mathrm{mg}^{-1} \mathrm{I}^{-1}\right]}\end{array}$ \\
\hline \multirow{2}{*}{ Before injection } & $\mathrm{T}$ & $2.38 \pm 1.71$ & $0.75 \pm 0.19$ & $8.13 \pm 4.60$ \\
\hline & C & $2.27 \pm 1.28$ & $0.91 \pm 0.22$ & $7.87 \pm 4.14$ \\
\hline \multirow{2}{*}{ Before surgery } & $\mathrm{T}$ & $13.4 \pm 5.16^{*}$ & $1.25 \pm 0.20^{*}$ & $10.9 \pm 7.10$ \\
\hline & C & $2.33 \pm 1.23$ & $0.91 \pm 0.23$ & $13.7 \pm 11.6$ \\
\hline \multirow{2}{*}{ Immediately AS } & $\mathrm{T}$ & $15.9 \pm 3.85^{*}$ & $1.12 \pm 0.20^{*}$ & $48.0 \pm 24.8$ \\
\hline & C & $2.02 \pm 0.85$ & $0.88 \pm 0.21$ & $58.9 \pm 41.0$ \\
\hline \multirow{2}{*}{$15 \mathrm{~min} A S$} & $\mathrm{~T}$ & $15.2 \pm 4.15^{*}$ & $1.10 \pm 0.20$ & $43.8 \pm 20.7$ \\
\hline & C & $2.01 \pm 0.90$ & $0.89 \pm 0.19$ & $59.7 \pm 30.6$ \\
\hline \multirow{2}{*}{$30 \mathrm{~min}$ AS } & $\mathrm{T}$ & $16.5 \pm 3.60^{*}$ & $1.18 \pm 0.22^{*}$ & $44.5 \pm 19.4$ \\
\hline & C & $2.05 \pm 0.79$ & $0.86 \pm 0.18$ & $61.1 \pm 28.7$ \\
\hline \multirow{2}{*}{$60 \mathrm{~min} A S$} & $\mathrm{~T}$ & $16.7 \pm 3.81^{*}$ & $1.16 \pm 0.22^{*}$ & $56.7 \pm 28.8$ \\
\hline & C & $2.18 \pm 1.00$ & $0.84 \pm 0.17$ & $65.3 \pm 26.1$ \\
\hline \multirow{2}{*}{2 hours AS } & $\mathrm{T}$ & $17.6 \pm 3.18^{*}$ & $1.09 \pm 0.26^{*}$ & $26.6 \pm 16.5^{*}$ \\
\hline & C & $2.13 \pm 0.84$ & $0.90 \pm 0.21$ & $49.9 \pm 21.7$ \\
\hline \multirow[b]{2}{*}{5 hours AS } & $\mathrm{T}$ & $19.0 \pm 3.08^{*}$ & $1.08 \pm 0.19^{*}$ & $15.8 \pm 7.97$ \\
\hline & C & $2.11 \pm 0.91$ & $0.88 \pm 0.21$ & $21.8 \pm 11.1$ \\
\hline \multirow[b]{2}{*}{10 hours AS } & $\mathrm{T}$ & $20.6 \pm 2.53^{*}$ & $1.06 \pm 0.16^{*}$ & $9.04 \pm 5.19$ \\
\hline & $\mathrm{C}$ & $2.66 \pm 2.53$ & $0.95 \pm 0.25$ & $12.6 \pm 8.02$ \\
\hline \multirow{2}{*}{24 hours AS } & $\mathrm{T}$ & $21.6 \pm 2.60^{*}$ & $1.10 \pm 0.15$ & $9.41 \pm 9.70$ \\
\hline & C & $2.51 \pm 1.57$ & $0.98 \pm 0.25$ & $10.7 \pm 5.43$ \\
\hline Group effect & & $P<0.05$ & $P<0.05$ & $P<0.05$ \\
\hline Time effect & & $P<0.05$ & $P<0.05$ & $P<0.05$ \\
\hline
\end{tabular}

T - Treatment group (Vit E/Se); C-Control group (placebo); AS—after surgery;

*_-means within sampling times differ significantly $(P<0.05)$ (Bonferroni test)

selenium administration with holding the increased levels in comparison to initial ones during the whole study.

Serum cortisol concentrations increased in both groups after surgery (Table 1). The highest values were reached at one hour after surgery in both groups. A return to concentrations similar to the initial ones were observed 24 hours after the surgery. The ANOVA revealed a significant effect of vitamin $\mathrm{E}$ and selenium injection on plasma cortisol concentrations $(\mathrm{P}<0.05)$.
The initial serum concentrations of vitamin $\mathrm{E}$ were low in both groups but not clearly deficient [29]. The concentrations of vitamin E measured in our study were similar to those found by $\mathrm{P}$ o n te s et al. [23] in dairy cows around calvings. The serum concentrations of $\alpha$-tocopherol found ten hours after vitamin $\mathrm{E}$ and selenium injection were approximately as high as those in cattle reported by $\mathrm{Hidiroglou}$ and Laflamme [14] who used DL-a-tocopheryl acetate for intramuscular injection in 
a similar dosage (4500 IU per 250 -30 kg body weight). Thus, it can be assumed that concentrations of vitamin E, reached in the experimental animals within the surgical procedure, were high enough to be effective on a lipid peroxidation or other physiological reactions associated with the stress response in animals.

Similarly, the subcutaneous administration of selenium elevated the blood selenium in the experimental dairy cows within the complete experimental period ( 24 hours) which could create a different metabolic condition in animal tissues affecting multiple biochemical processes and reactions. These dynamics were similar to that previously reported by $\mathrm{Ch}$ orfi et al. [7] after subcutaneous Se injections of $0.13 \mathrm{mg} \cdot \mathrm{kg}^{-1}$ in feedlot heifers. In dairy cows receiving Se injections in our study, the mean concentrations of serum Se observed prior to the injection in the experimental and control group (0.75 and $0.91 \mu \mathrm{mol}^{-1} \mathrm{l}^{-1}$, respectively) were in the range of reference intervals for dairy cows [13]. Selenium is well known to be effective in reducing oxidative stress and the severity of several proinflammatory-based dairy cattle diseases such as mastitis and metritis [18]. Most of the antioxidant functions of Se were based on the reducing capacity of selenoproteins including the glutathione peroxidase (GPX) and thioredoxin reductase (TrxR) families [26].

Hopster et al. [15] concluded that $69.4 \%$ of 307 baseline cortisol samples had concentrations below $3 \mu \mathrm{g} . \mathrm{l}^{-1}$, whereas $13.7 \%$ of the samples contained $6 \mu \mathrm{g} \cdot \mathrm{l}^{-1}$ cortisol or more. The relatively higher mean cortisol values prior to surgery in our study (higher than $7.5 \mu \mathrm{g} .1^{-1}$ ) may be due to sickness and transport stress of the animals. The effect of surgery on plasma cortisol was significant, however, cortisol concentrations fell near to pre-surgery values by the end of the trial. Thus, the pattern of cortisol response to surgery was similar to the pattern seen in 5-6 monthold cattle after amputation dehorning [27]. Comparable to some other studies, a significant effect of vitamin $\mathrm{E}$ and selenium administration on cortisol levels could be observed in our study. The reduction effect of vitamin $\mathrm{E}$ on the production of cortisol has been shown in calves [24], cattle [6,11], and mice [16]. Dietary compounds with antioxidant activity reduce activation of the hypothalamicpituitary-adrenocortical axis in animals [8]. This may be due to an effect of vitamin E suppressing phospholipase A2 activity [5]. The enzyme phospholipase A2 is involved in ACTH secretion [1]. T a n ig u chi et al. [28] observed that broiler chickens supplemented with vitamin $\mathrm{E}$ and injected with ACTH had reduced corticosterone content in the adrenal glands. However, there was no inhibiting effect of vitamins $\mathrm{E}$ and $\mathrm{C}$ on the release of cortisol from bovine adrenocortical cells when stimulated with ACTH in vitro [19]. In addition, maternal Se supplementation of dams resulted in lower circulating cortisol concentrations in lamb offspring compared with lambs born from non-supplemented ewes [4]. In an experiment with a transportation stress in sheep, a depressive effect of trace element supplementation, including selenium, could be seen on cortisol levels in ewe lambs [20]. It was speculated that Se can act directly on blood cortisol by affecting the free radical-antioxidant capacity balance.

In conclusion, we have demonstrated that the single injection of $6 \mathrm{~g}$ of DL-a-tocopheryl acetate and $67 \mathrm{mg}$ of natrium selenite significantly increases the serum vitamin $\mathrm{E}$ and Se within 10 hours. In addition, the blood cortisol was reduced in the treated cows. This decrease in blood cortisol may suggest that vitamin $\mathrm{E}$ and selenium supplementation may be an effective method to minimize the stress response in dairy cows.

\section{REFERENCES}

1. Abou-Samra, A. B., Catt, K. J., Aguilera, G., 1986: Role of arachidonic acid in the regulation of adrenocorticotropin release from rat anterior pituitary cell cultures. Endocrinology, 119, 4, 1427-1431. DOI: 10.1210/endo-119-4-1427.

2. Bergamasco, L., Coetzee, J. F., Gehring, R., Murray, L., Song, T., Mosher, R. A., 2011: Effect of intravenous sodium salicylate administration prior to castration on plasma cortisol and electroencephalography parameters in calves. J. Vet. Pharmacol. Therap., 34, 6, 565-576. DOI: 10.1111/j.13652885.2011.01269.x.

3. Breazile, J. E., 1988: The physiology of stress and its relationship to mechanisms of disease and therapeutics. Vet. Clin. North Amer. Food Anim. Pract., 4, 3, 441-480.

4. Camacho, L. E., Meyer, A. M., Neville, T. L., Hammer, C. J. Redmer, D. A., Reynolds, L. P., et al., 2012: Neonatal hormone changes and growth in lambs born to dams receiving differing nutritional intakes and selenium supplementation during gestation. Reproduction, 144, 6, 23-35. DOI: 10.1111/j.1365-2885.2011.01269.x.

5. Cao, Y. Z., Karmin, O., Choy, P. C., Chan, A. C., 1987: Reg- 
ulation by vitamin $\mathrm{E}$ of phosphatidylcholine metabolism in rat heart. Biochem. J., 247, 3, 135-140.

6. Chandra, G., Aggarwalb, A., Kumarc, M., Singh, A. K., 2018: Effect of zinc and vitamin E supplementation on hormones and blood biochemicals in peri-partum Sahiwal cows. J. Trace Elem. Med. Biol., 50, 489—497. DOI: 10.1016/j.jtemb. 2018.02.015.

7. Chorfi, Y., Girard, V., Fournier, A., Couture, Y., 2011: Effect of subcutaneous selenium injection and supplementary selenium source on blood selenium and glutathione peroxidase in feedlot heifers. Can. Vet. J., 52, 10, 1089-1094.

8. Dhanalaskshmi, S., Srikumar, R., Manikandan, S., Parthasarathy, N. J., Devi, R.S., 2006: Antioxidant property of triphala on cold stress induced oxidative stress in experimental rats. J. Health Sci., 52, 6, 843-847.

9. Duffield, T. F., Lissemore, K. D., McBride, B. W., Leslie, K. E., 2009: Impact of hyperketonemia in early lactation dairy cows on health and production. J. Dairy Sci., 92, 571-580. DOI: $10.3168 /$ jds.2008-1507.

10. Earley, B., Murray, M., Prendiville, D. J., Pintado, B., Borque, C., Canali, E., 2011: The effect of transport by road and sea on physiology, immunity and behaviour of beef cattle. Res. Vet. Sci., 92, 3, 531-541. DOI: 10.1016/j.rvsc.2011. 04.002 .

11. Gupta, S., Kumar, H., Soni, J., 2005: Effect of vitamin E and selenium supplementation on concentrations of plasma cortisol and erythrocyte lipid peroxides and the incidence of retained foetal membranes in crossbred dairy cattle. Theriogenology, 64, 6, 1273-1286. DOI: 10.1016/j.theriogenology. 2005.03.008.

12. Halliwell, B., Gutteridege, J. M. C., 2007: Free Radicals in Biology and Medicine. 4th edn., Oxford University Press, $944 \mathrm{pp}$.

13. Herdt, T. H., Rumbeiha, W., Braselton, W. E., 2000: The use of blood analyses to evaluate mineral status in livestock. Vet. Clin. North Amer. Food Animal Pract., 16, 3, 423-444. DOI: 10.1016/s0749-0720(15)30078-5.

14. Hidiroglou, N., Laflamme, L. F., 1993: A dynamic evaluation of the bioavailability of the free and ester forms of vitamin E administered intramuscularly to beef cattle. Vet. Res., $24,1,79-88$.

15. Hopster, H., Van der Werf, J. T. N., Erkens, J. H. F., Blokhuis, H. J., 1999: Effects of repeated jugular puncture on plasma cortisol concentrations in loose-housed dairy cows. J. Anim. Sci., 77, 3, 708-714.

16. Lim, T. S., Putt, N., Safranski, D., Chung, C., Watson,
R. R., 1981: Effect of vitamin $\mathrm{E}$ on cell-mediated immune response and serum corticosterone in young and maturing mice. Immunology, 44, 2, 289-295.

17. Machlin, L. J., 1991: Vitamin E. In Machlin L. J. (Ed.): Handbook of Vitamins. 2nd edn., Marcel Dekker, Inc., New York and Basel, $341 \mathrm{pp}$.

18. Malbe, M., Klaassen, M., Fang, W., Myllys, V., Vikerpuir, M., Nyholm, K., et al., 1995: Comparisons of selenite and selenium yeast feed supplements on Se-incorporation, mastitis and leukocyte function in Se-deficient dairy cows. J. Vet. Med. (Series A), 42, 2, 111-121. DOI: 10.1111/j.1439-0442.1995. tb00362.x.

19. Montalvo, C. P., Díaz, N.H., Galdames, L. A., Andrés, M. E., Larraín, R. E., 2011: Short communication: Effect of vitamins $\mathrm{E}$ and $\mathrm{C}$ on cortisol production by bovine adrenocortical cells in vitro. J. Dairy Sci., 94, 7, 3495-3497. DOI: $10.3168 /$ jds.2010-3760.

20. Mousaie, A., Valizadeh, R., Naserian, A. A., Heidarpour, M., Mehrjerdi, H. K., 2014: Impacts of feeding selenium-methionine and chromium-methionine on performance, serum components, antioxidant status, and physiological responses to transportation stress of Baluchi ewe lambs. Biol. Trace Element. Res., 162, 1-3, 113-123. DOI: 10.1007/s12011-0140162-x.

21. Mudron, P., Herzog, K., Höltershinken, M., Rehage, J., 2007: Effects of abdominal surgery on thiobarbituric acid reactive substances and plasma anti-oxidative capacity in dairy cows. J. Vet. Med. (Series A), 54, 8, 441-444. DOI: 10.1111/ j.1439-0442.2007.00992.x.

22. Nakao, T., Sato, T., Moriyoshi, M., Kawata, K., 1994: Plasma cortisol response in dairy cows to vaginoscopy, genital palpation per rectum and artificial insemination. J. Vet. Med. (Series A), 41, 1-10, 16-21. DOI: 10.1111/j.1439-0442.1994. tb00060x.

23. Pontes, G. C. S., Monteiro P. L. J. Jr., Prata, A. B., Guardieiro, M. M., Pinto, D. A. M., Fernandes, G. O., 2015: Effect of injectable vitamin $\mathrm{E}$ on incidence of retained foetal membranes and reproductive performance of dairy cows. J. Dairy Sci., 98, 4, 2437-2449. DOI: 10.3168/jds.2014-8886.

24. Reddy, P. G., Morrill, J. L., Minocha, H. C., Stevenson, J. S., 1987: Vitamin E is immunostimulatory in calves. J. Dairy Sci., 70, 5, 993-999. DOI: 10.3168/jds.S0022-0302(87)80104-2.

25. Rodriguez, E. M., Sanz, M. T., Romero, C. D., 1994: Critical study of fluorometric determination of selenium in urine. Talanta, 41, 12 2025-2031. DOI: 10.1016/0039-9140(94) e0060-5. 
26. Sordillo, L. M., Contreras, G. A., Aitken, S. L., 2009: Metabolic factors affecting the inflammatory response of periparturient dairy cows. Anim. Health Res. Rev., 10, 1, 53-63. DOI: $10.1017 /$ S1466252309990016.

27. Sylvester, S. P., Stafford, K. J., Mellor, D. J., Bruce, R. A., Ward, R. N., 1998: Acute cortisol responses of calves to four methods of dehorning by amputation. Australian Vet. J., 76, 2, 123-126. DOI: 10.1111/j.1751-0813.1998.tb14544.x.
28. Taniguchi, N., Ohtsuka, A., Hayashi, K., 2001: A high dose of vitamin $\mathrm{E}$ inhibits adrenal corticosterone synthesis in chicken treated with ACTH. J. Nutr. Sci. Vitaminol. (Tokyo), 47, 1, 40—46. DOI: 10.3177/jnsv.47.40.

29. Weiss, W. P., Hogan, J. S., Todhunter, D. A., Smith, K. L., 1997: Effect of vitamin E supplementation in diets with a low concentration of selenium on mammary gland health of dairy cows. J. Dairy Sci., 80, 8, 1728-1737. DOI: 10.3168/jds. S0022-0302(97)76105-8.

Received September 25, 2020

Accepted October 27, 2020 